\title{
Habitat simplification affects nuclear-follower foraging association among stream fishes
}

\author{
Fabrício Barreto Teresa ${ }^{1}$, Renato de Mei Romero ${ }^{1}$, Lilian Casatti ${ }^{1}$ and José Sabino ${ }^{2}$
}

Nuclear-follower interaction is a particular kind of interspecific foraging association that includes a nuclear species, which dig in or inspect the bottom, and follower species, which access the food items made available by the nuclear. In this study we examined the effect of habitat structure on nuclear-follower relationship in a stream of Bodoquena Plateau, Central-West Brazil. Foraging associations were registered while snorkeling in 24 observation sessions, totaling six hours in unaltered and altered sites. Overall, 272 nuclear-follower associations were registered, having four species acting as nuclear and seven as followers. The dominant nuclear species were different in each site. Prochilodus lineatus was the main nuclear species in the altered site and Leporinus macrocephalus in the unaltered site. The richness of follower species was similar between sites, however, follower species abundance per interaction were significantly higher in the unaltered site than in the altered site. These differences seem to be a consequence of the alterations in assemblage composition and feeding behavior of the nuclear species that presumably are affected by different substrate composition and food availability between the structurally distinct areas.

A interação nuclear-seguidor é um tipo particular de associação alimentar interespecífica que envolve uma espécie nuclear, que revolve ou vasculha o substrato, e espécies seguidoras, que acessam os itens alimentares disponibilizados pela atividade do nuclear. Neste estudo investigamos o efeito da estrutura do habitat sobre essa interação em um riacho no Planalto da Bodoquena, Centro-Oeste do Brasil. Foram registradas 272 interações durante 24 sessões de observação subaquática em áreas estruturalmente inalteradas e alteradas. A espécie nuclear dominante diferiu entre as áreas. Prochilodus lineatus foi a espécie nuclear dominante das áreas alteradas, enquanto que Leporinus macrocephalus foi a espécie nuclear dominante nas áreas inalteradas. A riqueza de espécies seguidoras por interação não diferiu entre as áreas, entretanto a abundância de seguidores foi maior nas áreas inalteradas do que nas alteradas. Essas diferenças parecem ser consequência das modificações na composição da comunidade e no comportamento alimentar das espécies nucleares que são, por sua vez, decorrentes das diferenças na composição do substrato e disponibilidade de alimento entre as áreas estruturalmente distintas.

Key words: Bodoquena Plateau, Feeding behavior, Habitat heterogeneity, Interspecific interaction, Substrate.

\section{Introduction}

The nuclear-follower relationship is a kind of interespecific interaction that involves a nuclear species, that dig in or inspect the bottom usually for foraging and one or more follower species, which follow the nuclear species, capturing food items that were made available by them (Strand, 1988). In reef zones of marine environments, the nuclear-follower interaction is an important component of communities, involving a large number of species (Strand, 1988; Lukoschek \& McCormick, 2000; Sazima et al., 2007). In freshwater environments, the number of records of this interaction has increased with the increment of the naturalistic studies in these environments; even though, the occurrence of this interaction is apparently underestimated (Baker \& Foster, 1994; Leitão et al., 2007; Teresa \& Carvalho, 2008; GarroneNeto \& Sazima, 2009).

The presence of unconsolidated substrate and benthic species that revolve or search the substrate are examples of predictor attributes to the interaction occurrence (Strand, 1988; Sazima et al., 2007; Teresa \& Carvalho, 2008). However, other factors such as food distribution in the habitat and nuclear species behavior also influence the degree of disturbance caused by the nuclear species, and consequently the interaction profile (Matsumoto \& Kohda, 2001). This demonstrates that the nuclear-follower interaction can be influenced by different ecological factors, although few studies have been directed to this type of investigation.

${ }^{1}$ UNESP, Universidade Estadual Paulista, Laboratório de Ictiologia, Departamento de Zoologia e Botânica, IBILCE. Rua Cristóvão Colombo, 2265, 15054-000 São José do Rio Preto, SP, Brazil. fabricioteresa@yahoo.com.br, romerobio@yahoo.com.br, licasatti@gmail.com ${ }^{2}$ Universidade Anhanguera-Uniderp, Laboratório de Biodiversidade e Conservação de Ecossistemas Aquáticos. 79003-010 Campo Grande, MS, Brazil. sabino-jose@uol.com.br 
Physical habitat structure is one of the most important factors influencing ecology and behavior of stream fish (Gorman \& Karr, 1978; Almany, 2004; Lee \& Berejikian, 2009). Alterations of the interspecific interactions, among them the nuclear follower association, caused by extrinsic factors such as physical ones may occur by their effects on (i) determining presence or absence of the one or both interactive species or (ii) affecting specific traits of the interactive species such as behavior or cost/benefits trade off of engaging in the interaction, reducing or increasing interaction occurrence probability. In this study we tested if nuclear-follower feeding association is affected by physical habitat condition. We evaluated nuclearfollower interaction in structurally distinct stretches in a stream of the Bodoquena Plateau, Central-West Brazil, a region that encompasses streams where this interaction is common and involves a large number of species, being an issue of several ongoing researches (J. Sabino \& L. P. Andrade, unpub. data). Specifically, the following main questions were addressed in the present study: (i) Does the composition and frequency of species acting as nuclear and follower species differ between structurally distinct areas? (ii) Does the richness and abundance of follower species differ between structurally distinct areas? (iii) Does the identity of the nuclear species influence the richness and abundance of follower species? The answers to these questions provide new insights about factors modulating nuclear-follower associations and contribute to a broader comprehension of the physical habitat simplification impacts on fish communities.

\section{Material and Methods}

The study was carried out in the stream named córrego Olho d'Água (Fig. 1), located in the Jardim Municipality, Bodoquena Plateau, Mato Grosso do Sul State, Central-West Brazil, upper rio Paraguay basin. This basin is included in the La Plata-Uruguay-Paraná-Paraguay system, the second largest
(3.2 millions $\mathrm{km}^{2}$ ) drainage system in South America (Lowe-

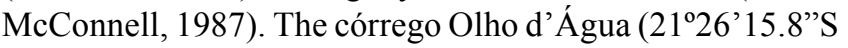
$56^{\circ} 26^{\prime} 41.5$ "W) shows high underwater transparency (frequently further than $30 \mathrm{~m}$ ), width from 10 to $12 \mathrm{~m}$, depth from 0.30 to $1 \mathrm{~m}$, sandy substrate with trunks, branches, and rooted submerged macrophytes.

Córrego Olho d'Água is used for recreational activities consisting of contemplating the aquatic ecosystem through snorkeling. Continuously, day after day, tourists snorkel down the stream, following a defined way called "underwater trail". On this trail, macrophytes, trunks and branches are scarce due to the continuous contact of tourists with the bottom, resulting in structural modification of these stretches. As a result of this activity, some stretches, specially shallow waters, are composed of two structurally distinct areas: one simplified with small amounts of submerged rooted macrophytes, few logs, and substrate predominantly sandy, above of which there is a thin layer of organic matter (epipelon); another representing a contiguous area where tourists have restricted access, presenting vast banks of submerged rooted macrophytes, branches, trunks, and substrate composed of a thick layer of algae and plant debris. These structurally distinct areas are hereafter called "altered" and "unaltered" sites, respectively. The study was conducted in one of each type of areas of $80 \mathrm{~m}^{2}$ each (Fig. 2).

Underwater observations were done by two divers, from 4:00 to 6:00 PM, in both sites, after daily tourist activities had finished, minimizing the possible effects of tourist passage on the focused interaction. Overall, 24 sessions were conducted over three months (May, July, and September 2008), totaling six hours of observations. In each interacting event, the nuclear and followers identities were visually determined, as well as the followers abundance. An event of interaction was considered the approximation of followers within a radius of approximately $50 \mathrm{~cm}$ of another individual who was causing disturbance to the substrate (nuclear).
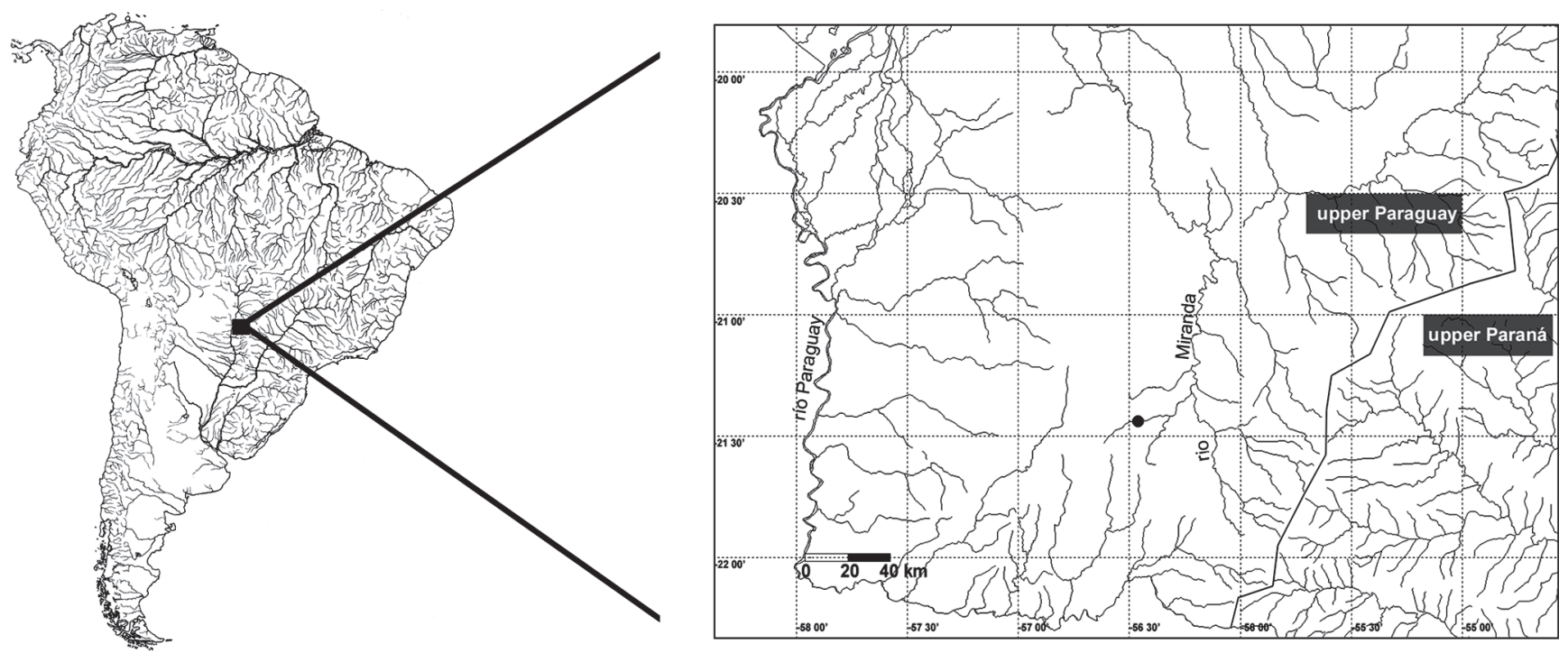

Fig. 1. Location of the study area, indicating the córrego Olho d'Água in South America (black dot). 


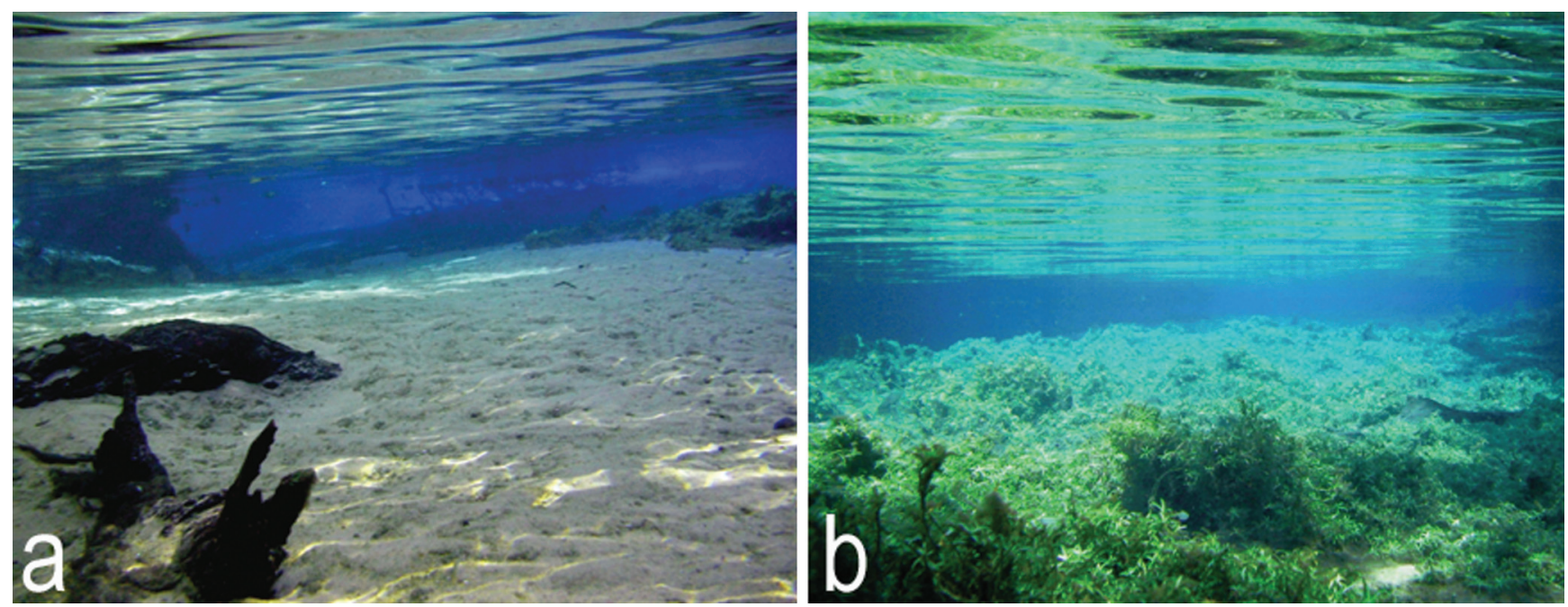

Fig. 2. General view of the altered (a) and unaltered (b) sites in the córrego Olho d'Água, Central-West Brazil. Photos: Renato M. Romero and Fabrício B. Teresa.

The relative frequency of each species acting as nuclear per interaction, richness and abundance of followers per interaction were compared using the Chi-Square test. The abundance of followers was evaluated in categories ( 1 to $5 ; 6$ to $10 ; 11$ to 15 ; more than 16 individuals). In order to assess whether changes of follower richness and abundance across sites is dependent of the nuclear species, comparisons between sites were also carried out considering each predominant nuclear species separately. When Chi-Square assumptions were violated the maximum likelihood estimate was used.

\section{Results}

Overall, 272 feeding nuclear-follower associations were registered, with 148 in altered and 124 in unaltered sites. In all cases only one individual acted as nuclear in every interaction. Five species were nuclear: Prochilodus lineatus, Leporinus macrocephalus, Leporinus friderici, Brycon hilarii, and Piaractus mesopotamicus. Seven species were followers: Astyanax asuncionensis, Astyanax marionae, Astyanax lineatus, Crenicichla lepidota, Crenicichla vittata, Moenkhausia bonita, and Jupiaba acanthogaster.

Prochilodus lineatus and L. macrocephalus acted as nuclear in $93.4 \%$ of the recorded interactions. However, the frequency in which these species acted as nuclear differ among altered and unaltered sites $\left(\chi^{2}=89.59, \mathrm{p}<0.001\right)$. Prochilodus lineatus was the main nuclear species in the altered site, participating of the interaction in a proportion higher than that observed in the unaltered site $\left(\chi^{2}=81.36, p<0.001\right)$ (Table 1). Behavioral differences were also observed for this species between sites. In the altered site, P. lineatus individuals repeatedly grasped the substrate while moving during their feeding activity, whereas in the unaltered site, the contact with the bottom was done with simple bites at longer intervals.
Leporinus macrocephalus was the main nuclear species in the unaltered site, acting as nuclear in a proportion higher than the observed in the altered site $\left(\chi^{2}=62.00, \mathrm{p}<0.001\right)$ (Table 1). The feeding behavior of $L$. macrocephalus was also different between sites. In the unaltered site, individuals introduced their snouts and ate portions of the thick layer of algae and plant debris, which were abundant in these areas, performing vigorous movements with the body to pluck them, promoting the disturbance of large amounts of sediment; in the altered site individuals usually softly lunge against the bottom, biting off small portions of substrate, therefore resulting in slight sediment suspension.

Brycon hilarii served as nuclear only in the unaltered site $\left(\chi^{2}=9.59, p=0.002\right)$. The other species did not differ in the frequency in which they acted as nuclear between areas $(p>0.22)$ and together accounted for $2.7 \%$ and $6.4 \%$ of interactions in the altered and unaltered sites, respectively.

The number of follower species in each interaction varied from one to four. Nuclear species were accompanied by one follower species in $72.1 \%$ of interactions, by two in $26.1 \%$, by three in $1.5 \%$ and by four species in only one occasion $(0.4 \%)$. Sites showed similar number of species acting as followers $\left(\chi^{2}=2.91, p=0.41\right)$; however, the frequency in which some follower species were involved in the interaction varied between sites. Jupiaba acanthogaster was the main follower species in both sites, being present in $92.3 \%$ of interactions. However, in the unaltered site, the dominance of this species as a follower was higher $\left(\chi^{2}=11.93, \mathrm{p}<0.001\right)$ (Table 2). Astyanax marionae and C. lepidota acted as followers mainly in the unaltered site $\left(\right.$ A. marionae: $\chi^{2}=24.02$, $\mathrm{p}<0.01$; C. lepidota: $\chi^{2}=4.92, \mathrm{p}=0.03$ ) (Table 2). Crenicichla vittata served as a follower only in the altered site $\left(\chi^{2}=29.31, \mathrm{p}<0.001\right)$ (Table 2). Astyanax asuncionensis, A. lineatus, and M. bonita acted as followers in $2.2 \%$ of interactions, having no statistical differences between sites (Table 2). 
Table 1. Frequency of species acting as nuclear in the altered and unaltered sites, córrego Olho d'Água, Central-West Brazil. Numbers in parenthesis indicate percentage. *indicates $\mathrm{p}<0.05$ in between areas comparison.

\begin{tabular}{lcc}
\hline Species & Altered & Unaltered \\
\hline Prochilodus lineatus & $125(84.5)^{*}$ & $38(30.7)$ \\
Leporinus macrocephalus & $19(12.8)^{*}$ & $72(58.1)$ \\
Leporinus friderici & $3(2.0)$ & $5(4.0)$ \\
Piaractus mesopotamicus & $1(0.7)$ & $3(2.4)$ \\
Brycon hilarii & $0(0)^{*}$ & $6(4.8)$ \\
\hline Total & $148(100)$ & $124(100)$ \\
\hline
\end{tabular}

The abundance of followers per interaction, represented by categories of abundance, differed between sites $\left(\chi^{2}=45.99\right.$, $\mathrm{p}<0.001)$. In an analysis considering the two nuclear species responsible for most interactions, $P$. lineatus and $L$. macrocephalus separately, species richness of followers attracted per interaction did not differ between sites $(P$. lineatus: $\chi^{2}=3.13, \mathrm{p}=0.37 ;$ L. macrocephalus: $\chi^{2}=3.84, \mathrm{p}=$ $0.15)$. There was no difference between sites in the abundance of followers attracted by $P$. lineatus $\left(\chi^{2}=4.15, \mathrm{p}=0.24\right)$. However, abundance of followers that L. macrocephalus atracted per interaction did differ between sites $\left(\chi^{2}=14.5\right.$, $\mathrm{p}=0.003)$. A lower proportion of interactions $\left(\chi^{2}=9.97, \mathrm{p}=\right.$ 0.002 ) envolving L. macrocephalus and smaller groups of followers ( 1 to 5 individuals) and a higher proportion of interactions $\left(\chi^{2}=5.51, \mathrm{p}=0.02\right)$ with larger groups of followers ( $>16$ individuals) was registered in the unaltered areas compared to altered.

\section{Discussion}

The fact that the present study was performed in adjacent areas minimizes the possible differential effects of the tourist's passage, as well as other variables such as hydrology that may affect fish behavior. In another study conducted on site, with the purpose of investigating the effects of tourism on different ichthyofauna descriptors, no direct effect of the passage of tourists were detected, so that the interference from variables other than structural differences between areas was reduced. In this sense, the structural differences between altered and unaltered sites were sufficient to affect the nuclearfollower interaction profile. Although the association has been recorded in both sites, these changes were represented by differences in nuclear species composition, abundance and composition of followers.

Substrate disturbance is one of the most important predictors for the species acting as nuclear (Sazima et al., 2007; Krajewski, 2009). This is consistent with the results of the present study, since nuclear dominant species (P. lineatus and L. macrocephalus), that accounted for $93.4 \%$ of interactions, feed on benthic resources, causing the suspension of sediment during their feeding activities. Prochilodus lineatus individuals are iliophagous, feeding on detritus embedded in the sediment; when feeding they project their lips against the bottom and snap portions of
Table 2. Frequency of species acting as followers in the altered and unaltered sites, córrego Olho d'Água, Central-West Brazil. Numbers in parenthesis indicate percentage. Total does not reach $100 \%$ because some interactions occurred with more than one follower species. *indicates $\mathrm{p}<0.05$ in between areas comparison.

\begin{tabular}{lcc}
\hline Species & Altered & Unaltered \\
\hline Jupiaba acanthogaster & $129(87.2)^{*}$ & $122(98.4)$ \\
Crenicichla vittata & $31(20.9)^{*}$ & $0(0)$ \\
Crenicichla lepidota & $7(4.7)^{*}$ & $15(12.1)$ \\
Astyanax marionae & $3(2.0)^{*}$ & $25(20.2)$ \\
Astyanax asuncionensis & $1(0.7)$ & $2(1.6)$ \\
Astyanax lineatus & $1(0.7)$ & $0(0)$ \\
Moenkhausia bonita & $2(1.4)$ & $0(0)$ \\
\hline
\end{tabular}

the substrate (Fugi et al., 1996). Leporinus macrocephalus individuals are omnivorous that use distinct feeding tactics, among them "picking at relatively small prey" (sensu Keenleyside, 1979) close to the bottom. Nevertheless, the feeding behavior of $P$. lineatus and L. macrocephalus differed among sites and influenced the nuclear-follower interaction profile. These differences are apparently the result of unequal types and quantities of food between sites. For L. macrocephalus, algae layer and plant debris in unaltered site demanded more vigorous movements so that their pieces were pulled out, while small bites on the substrate were sufficient to capture portions of the thin layer of this epipelon in the altered site. For $P$. lineatus, a higher frequency of lunges on the bottom in the altered site may represent a compensatory activity in response to a smaller amount of food present on the sandy bottom.

The vigorous movement of $L$. macrocephalus individuals and the repeated bites of $P$. lineatus to obtain food in the unaltered and altered sites, respectively, were those activities that promoted greater disturbance and suspension of sediment in these areas, which explains the predominance of these species as being the main nuclear under these conditions. The positive relationship between the attraction of followers and disturbance in the bottom during nuclear species activities has been observed in other studies (Matsumoto \& Kohda, 2001; Krajewski, 2009). For example, Matsumoto \& Kohda (2001) observed, in southern Japan, that the performance of repeated bites instead of simple bites by individuals of the reef fish Goniistius zonatus (=Cheilodactylus zonatus) resulted in greater substrate disturbance and, consequently, greater availability of food for the followers, increasing frequency and duration of the feeding association. Similarly, the positive correlation between richness and abundance of followers with abundance of the nuclear reef fish Pseudupeneus maculatus in foraging activity was attributed to the amount of disturbance caused by the nuclear species, which would be greater for large groups than in small groups or for solitary foraging animals (Sazima et al., 2006).

The role of herbivorous species, like Brycon and Piaractus, as nuclear is unusual, in detriment of zoobenthivorous habit that is usually associated with nuclear 
species (Sazima et al., 2007). During their foraging activity, individuals of these browsers species (sensu Sazima, 1986) bite off portions of aquatic vegetation, tearing them off with abrupt movements. When removing this vegetation, individuals move large portions of vegetation, resulting in the suspension of sediment and attracting followers. Just occasionally these species serve as nuclear and, in the case of Brycon, only in the unaltered site, which can be explained by the low abundance of macrophytes in disturbed locations.

Jupiaba acanthogaster, the dominant species acting as follower has its occurrence associated specially to headwaters streams (Teresa \& Romero, 2010) and is the most common species in the córrego Olho d'Água. According to Willink et al. (2000), this species exhibits a large phenotypic plasticity, with the ability to occupy different habitats. This species fits the generalization that species which regularly act as followers are small, generalist, and opportunistic (Strand, 1988; Teresa \& Carvalho, 2008). However, in the unaltered site this species served as follower more frequently than in altered, as did C. lepidota and $A$. marionae, and in contrast to $C$. vittata, which was a follower exclusively of the altered site. One explanation for the differential performance of these species would be the unequal abundance of their populations between areas, representing a density-dependent effect. This seems to be the case of $C$. lepidota which is, in fact, more abundant in unaltered sites. This species has breeding and parental care associated to macrophytes, trunks and branches (Sabino \& Andrade, 2003), elements that are rare in simplified conditions.

Other factors that are not dependent on the fish density can also contribute to the differential performance of species as followers. For example, the selectivity that followers have in relation to nuclear species that generate greater local disturbance (Strand, 1988) that, in turn, varies in function of behavioral and feeding habitat traits (Strand, 1988; Sazima et al., 2006). Although the differences of feeding habits and behavior vary among species, the amount of disturbance caused on the bottom also may to vary within the same species. In this case the degree of disturbance caused by nuclear individuals can be environmentally dependent (Matsumoto \& Kohda, 2001; this study), so that followers can be selective not only with respect to the nuclear species but also to the best places to interact. Present results indicate that these places are located in the unaltered site, which possess the bottom covered by greater amount of particulate matter that is more easily suspended during nuclear activity.

Despite the richness of followers in each interaction to be similar between sites, interactions involving more numerous groups of followers were more frequent in the unaltered site than in the altered site. However, this was dependent on the nuclear species, as $P$. lineatus attracted the same number of individuals per interaction in both sites, while there was a higher frequency of interactions involving L. macrocephalus with large groups of followers in the unaltered site.
The main advantage for followers to engage in foraging associations is the acquisition of food resources that would be totally or partially inaccessible (Lukoschek \& McCormick, 2000). Food acquisition by followers is suggested as being significant to fish reefs assemblages (Strand, 1988; Lukoschek $\&$ McCormick, 2000; Sazima et al., 2007). Although there is little information about the importance of nuclear-follower foraging association for freshwater fish communities, the number of species involved and the frequency of interaction registered in this study is an indicative of its significance in these ecosystems. Moreover, the results obtained here suggest that the nuclear-follower association profile is context-dependent, varying in accordance to physical habitat structure. In this way, the habitat simplification, a common anthropogenic impact in Neotropical streams, not only affects fish at individual and population levels, but also at community level through its effects on the interspecific interactions (i.e., foraging association). We attribute this effect to the alterations in assemblage composition and feeding behavior of nuclear species that are affected by differential substrate composition and food availability between the structurally distinct areas.

\section{Acknowledgements}

This study is part of the project "Fish as indicators of streams water quality in urban and tourist areas in Bodoquena Plateau, Mato Grosso do Sul" (MCT/CNPq/CTHidro n $39 / 2006$ ) and the project "Biodiversity and conservation of the ichthyofauna of the Bodoquena Plateau: index of biotic integrity, eco-physiology, and behavior applied to sustainable tourism" (FUNDECT/Call $n^{\circ} 04 / 2005$ - Research Network). Authors are thankful to Eduardo F. Coelho and team for permission and logistical support to carry out the study on their property and the logistical support offered by the Cabeceira do Prata Farm. David R. Mercer revised English language. FBT and RMR receive grants from FAPESP (2008/03583-9, 2007/05400-6), LC and JS receives grants from CNPq (303647/2007-8, 306169/2008-8).

\section{Literature Cited}

Almany, G. R. 2004. Does increased habitat complexity reduce predation and competition in coral reef fish assemblages? Oikos, 106(2): 275-284.

Baker, J. A. \& S. A. Foster. 1994. Observations on a foraging association between two freshwater stream fishes. Ecology of Freshwater Fish, 3(3): 137-139.

Fugi, R., N. S. Hahn \& A. A. Agostinho. 1996. Feeding styles of five species of bottom-feeding fishes of the High Paraná River. Environmental Biology of Fishes, 46(3): 297-307.

Garrone-Neto, D. \& I. Sazima. 2009. Stirring, charging, and picking: hunting tactics of potamotrygonid rays in the upper Paraná River. Neotropical Ichthyology, 7(1): 113-116.

Gorman, O. T. \& J. R. Karr. 1978. Habitat structure and stream fish communities. Ecology, 59(3): 507-515.

Keenleyside, M. H. A. 1979. Diversity and adaptation in fish behaviour. Berlin, Springer, 208p.

Krajewski, J. P. 2009. How do follower reef fishes find nuclear fishes? Environmental Biology of Fishes, 86(3): 379-387. 
Lee, J. S. F. \& B. A. Berejikian. 2009. Structural complexity in relation to the habitat preferences, territoriality, and hatchery rearing of juvenile China rockfish (Sebastes nebulosus). Environmental Biology of Fishes, 84(4): 411-419.

Leitão, R. P., E. P. Caramaschi \& J. Zuanon. 2007. Following food clouds: feeding association between a minute loricariid and a characidiin species in an Atlantic Forest stream, Southeastern Brazil. Neotropical Ichthyology, 5(3): 307-310.

Lowe-McConnell, R. H. 1987. Ecological studies in tropical fish communities. Cambridge, Cambridge University Press, $382 \mathrm{p}$.

Lukoschek, V. \& M. I. McCormick. 2000. A review of multispecies foraging associations in fishes and their ecological significance. Proceedings of the $9^{\text {th }}$ International Coral Reef Symposium, 1: 467-474.

Matsumoto, K. \& M. Kohda. 2001. Differences in feeding associations of benthophagous fishes in two locations. Environmental Biology of Fishes, 61(1): 111-115.

Sabino, J. \& L. P. Andrade. 2003. Uso e conservação da ictiofauna na região de Bonito, Mato Grosso do Sul: o mito da sustentabilidade ecológica no rio Baía Bonita (Aquário Natural de Bonito). Biota Neotropica, 3(2): 1-9.

Sazima, C., J. P. Krajewski, R. M. Bonaldo \& P. R. Guimarães-Jr. 2006. The goatfish Pseudupeneus maculatus and its follower fishes at an oceanic island in the tropical west Atlantic. Journal of Fish Biology, 69(3): 883-891.
Sazima, C., J. P. Krajewski, R. M. Bonaldo \& I. Sazima. 2007. Nuclearfollower foraging associations of reef fishes and other animals at an oceanic archipelago. Environmental Biology of Fishes, 78(4): 1-11.

Sazima, I. 1986. Similarities in feeding behaviour between some marine and freshwater fishes in two tropical communities. Journal of Fish Biology, 29(1): 53-65.

Strand, S. 1988. Following behavior: interspecific foraging associations among Gulf of California reef fishes. Copeia, 1988(2): 351-357.

Teresa, F. B. \& F. R. Carvalho. 2008. Feeding association between benthic and nektonic Neotropical stream fishes. Neotropical Ichthyology, 6(1): 109-111.

Teresa, F. B. \& R. M. Romero. 2010. Influence of the riparian zone phytophysiognomies on the longitudinal distribution of fishes: evidence in a Brazilian savanna stream. Neotropical Ichthyology, 8(1): 163-170.

Willink, P. W, O. Froehlich, A. Machado-Alisson, N. Menezes, O. Oyakawa, A. Catella, B. Chernoff, F. C. T. Lima, M. ToledoPiza, H. Hortega, A. M. Zanata \& R. Barriga. 2000. Fishes of the Rio Negro, Negrinho, Taboco, Aquidauana, Taquari and Miranda, Pantanal, Brasil: diversity, distribution, critical habitats and value. Pp. 63-81. In: Willink, P. W., B. Chernoff, L. E. Alonso, J. R. Montambault \& R. Lourival (Eds.). A Biological Assessment of the Aquatic Ecosystems of the Pantanal, Mato Grosso do Sul, Brasil. Bulletin of Biological Assessment 18, Conservation International, Washington, D. C., 307p.

Accepted November 9, 2010 Published March 31, 2011 